\title{
Three-Dimensional Analysis of a Landslide Process on a Slope in Carpathian Flysch
}

\author{
Lesław Zabuski \\ Institute of Hydro-Engineering, Polish Academy of Sciences, 7 Kościerska, 80-328 Gdańsk, Poland, \\ e-mail: leslawzabuski@ibwpan.gda.pl
}

(Received June 17, 2019; revised August 05, 2019)

\begin{abstract}
The paper presents a 3D (spatial) analysis of deformation processes in the landslide slope Bystrzyca in Szymbark near Gorlice (Low Beskid - Carpathians; N 49 37'09', E $21^{\circ} 05^{\prime} 49^{\prime \prime}$ ) carried out by the computer code FLAC3D based on the finite difference method. The numerical analysis was performed to determine the influence of the orientation of layers and discontinuities and of hydrogeological conditions on slope deformations and the failure mechanism during sliding processes. The massif is modeled as an elasto-plastic medium obeying the Coulomb-Mohr criterion. Two variants of hydrogeological conditions are analyzed, namely the "dry slope" (without water) and the "wet slope" (entirely saturated). The influence of the orientation of discontinuities (modeled as "ubiquitous") on the landslide mechanism is investigated as well. Few orientations of discontinuities with respect to the dip direction of the slope surface are considered, namely consequent, insequent, and subsequent (two variants in each case). The results show a clear impact of the pattern of discontinuities and hydrogeological conditions on the deformational behavior of the landslide and the shape of the slip surface. The 3D approach and results of the numerical simulation of the landslide movement prove the necessity of 3D modeling in some cases.
\end{abstract}

Key words: Carpathian flysch, landslide, discontinuity, 3D numerical calculations, displacement

\section{Introduction}

The basic aim of the paper is to determine the influence of the orientation of layers and discontinuities and of hydrogeological conditions on slope deformations and the failure mechanism during sliding processes in the landslide slope Bystrzyca in Szymbark near Gorlice - Low Beskid, the Carpathians (Fig. 1). The computer program FLAC3D was applied in the analysis, which was based on the finite difference method (Itasca 1997, Detournay, Hart 1999, Hungr et al 1989, Zabuski 2006, 2018). This method is

(C) 2019 Institute of Hydro-Engineering of the Polish Academy of Sciences. This is an open access article licensed under the Creative Commons Attribution-NonCommercial-NoDerivs License (http://creativecommons.org/licenses/by-nc-nd/3.0/). 


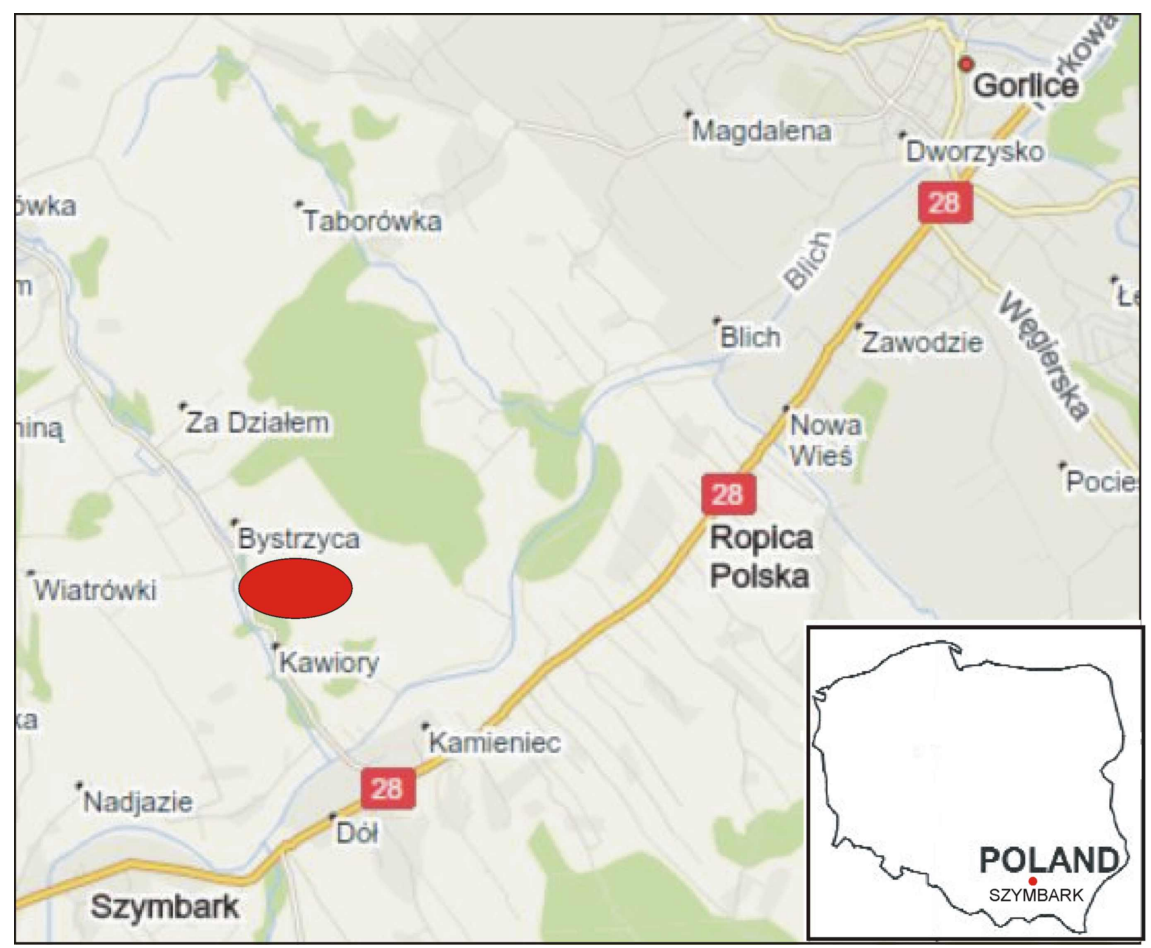

Fig. 1. Location of the landslide

an accurate and versatile approach to the analysis of both the stability and displacement of objects in rock and soil media. Its advantage is that it makes no assumptions about the failure mechanism. In contrast to the traditional "limit equilibrium" analysis, this method provides a full solution to the coupled stress/displacement, equilibrium and constitutive equations. The FLAC program calculates the stress/strain distribution as well displacements for different models of the medium - in this case, an elasto-plastic model. The slope analyzed here is divided into finite difference zones, and the program calculates stress and displacement, and determines the mode of failure (if it occurs) in each zone or in the mesh node. Changes in the shape of the slope are tracked and registered thanks to the Lagrange formalism.

Physical investigations of the slope began approximately 30 years ago (Thiel ed.1989). Some aspects were solved in the following years (Zabuski et al 1999, Zabuski 2008). It was only last year, however, that an advanced numerical 3D analysis was performed, making it possible to determine the influence of the layer and discontinuity orientation and of hydrogeological conditions on slope deformations and the failure mechanism during the sliding process. It should be underlined that 3D analysis is necessary in many cases (Griffiths and Marquez 2007, Stark and Eid 1998, Chen and Chameau 1982, Silvestri 2006, Lam and Fredlund 1993, Zabuski 2006), especially when: 
- the landslide is relatively narrow, and the effect of lateral constraints (lateral walls) should be taken into account - in other words, when the assumption of the plane strain state is not fulfilled,

- the shape of the landslide is irregular,

- the "degree" of deformation engagement in different parts of the landslide slope is different,

- signs of displacement in a direction perpendicular to the slope inclination are visible - it is impossible to evaluate this displacement in the plane strain state (i.e. in two dimensions),

- rock layers and discontinuity systems are dipping (falling) oblique with respect to the general inclination (dip direction) of the slope,

- the landslide slope is or will be undercut (naturally or artificially) along only part of its base,

- an external load acts in a direction that does not agree with the general inclination of the slope.

The Low Beskid is a region with a large number and a high density of landslides. Therefore, many investigations of these phenomena have been carried out (e.g. Dauksza and Kotarba 1973, Zabuski et al 2009). Systematic investigations of the Bystrzyca landslide were performed in the 1980s (Thiel ed. 1989). Since then, i.e. for almost 40 years, investigations of the landslide have been performed only occasionally (Zabuski et al 1999, Zabuski 2008). Geodetic measurements have been carried out in recent years, and the actual shape of the landslide has been determined. They served as the basis for developing a numerical model of the slope.

In this paper, the geology and morphology of the landslide are analyzed, and the deformations are calculated by a three-dimensional (3D) numerical model. The massif is modeled as an elasto-plastic medium obeying the Coulomb-Mohr criterion. Two variants of hydrogeological conditions are analyzed, namely the "dry slope" (without water) and the "wet slope" (entirely saturated with water). The influence of the orientation of discontinuity (modeled as "ubiquitous") on the landslide mechanism is investigated. Three orientations of interbedding discontinuities with respect to the orientation of the slope are considered, namely consequent, insequent, and subsequent (two variants in the last two cases). The orientation of discontinuities is "consequent" both with the dip direction of the slope and with slope inclination. In the case of the "insequent" orientation, the dip direction of discontinuities is the same as dip direction of the slope, but their dip angles are different. In the "subsequent" configuration, both the dip directions and dip angles of discontinuities and of the slope are different (Bober and Zabuski 1993, Bober et al 1997, Zabuski et al 1999).

It was only last year that an advanced numerical $3 \mathrm{D}$ analysis was performed, which made it possible to determine the influence of the layer and discontinuity orientation and of hydrogeological conditions on slope deformations and the failure mechanism during the sliding process. 


\section{General Description of the Landslide}

The landslide occupies a fragment of a larger slope and is situated between the Bystrzanka stream (315 m a.s.l) and the Taborówka Hill, $410 \mathrm{~m}$ a.s.l. (Fig. 2). The slope is gently inclined towards the Bystrzanka valley. Its inclination angle is on average $7.5^{\circ}$ but locally increases to $18^{\circ}$ (Fig. 3). The landslide is located in the marginal region of the Magura nappe, one of the tectonic units of the Carpathian flysch. The slope is composed of formations belonging to the northern thrust, built of Inoceramus layers (upper Cretaceous), constituted as sandstones and Eocene variegated shales. Sand-stone layers are interlayered by clay shale complexes. In the upper part of the slope, built of sandstone and shale, Inoceramus layers and red Eocene shales are visible.

It is an old undated landslide classified as mature. The initial forms of the slope have been significantly transformed by former intensive displacements. Sharp edges of the main scarps, bulges, and a clear edge of the landslide tongue are observed. Lateral scarps are most clearly visible in the upper and middle parts of the landslide. On the surface, folds of the accumulated colluvium material, hummocky superficial irregular tongues, marginal ramparts, and benches, as well as tension and subsidence cracks are seen.

Inoceramus layers constituting the landslide bedrock dip at $18^{\circ}-35^{\circ}$. Three systems of discontinuities, dipping mainly towards the south, intersect the rock mass, which results in extensive fractures. The original structure of the mass in the colluvium is destroyed and therefore chaotic.

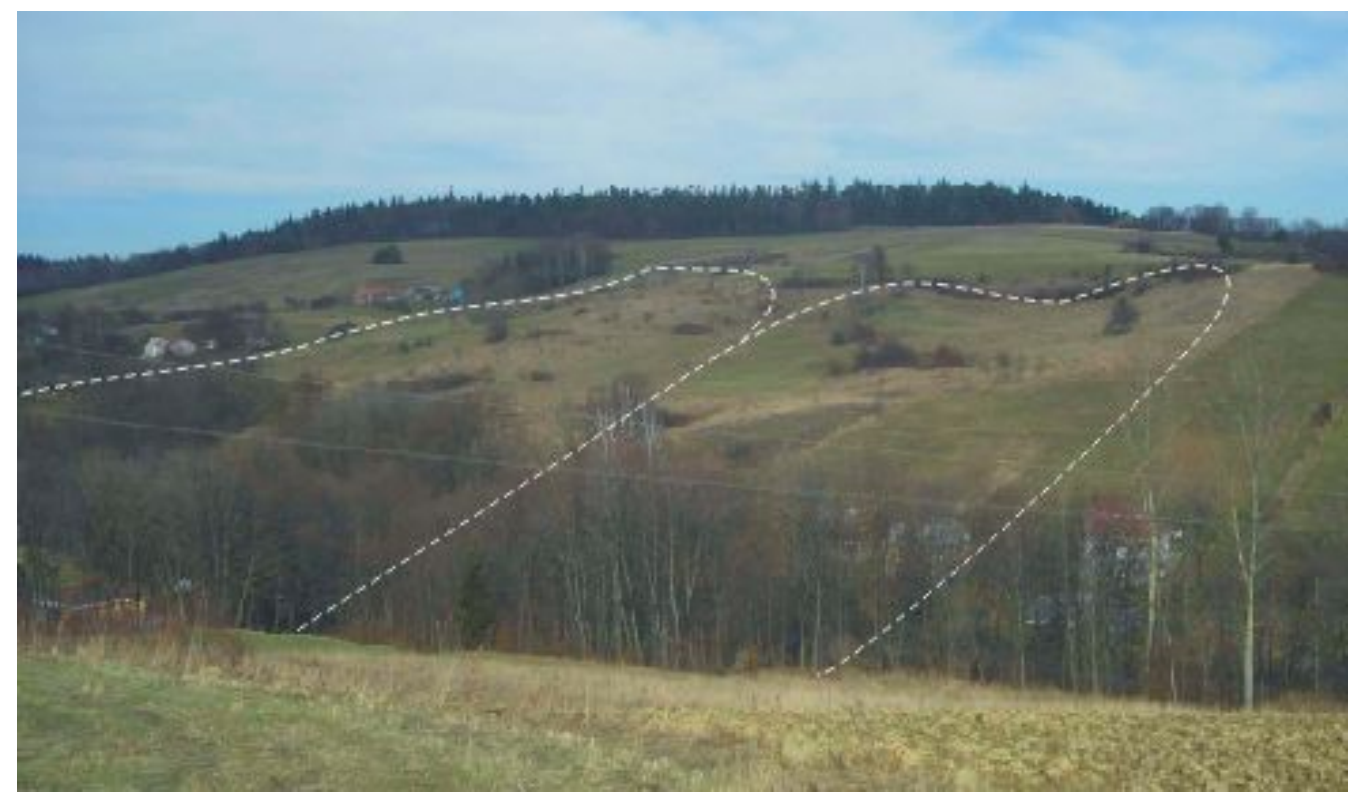

Fig. 2. General view of the "Bystrzyca" landslide 
The landslide is laterally confined by faults and zones of tectonic disturbances. The main scarps were created by detachment along the layers and discontinuities. In effect, the landslide shape is a function of tectonics.

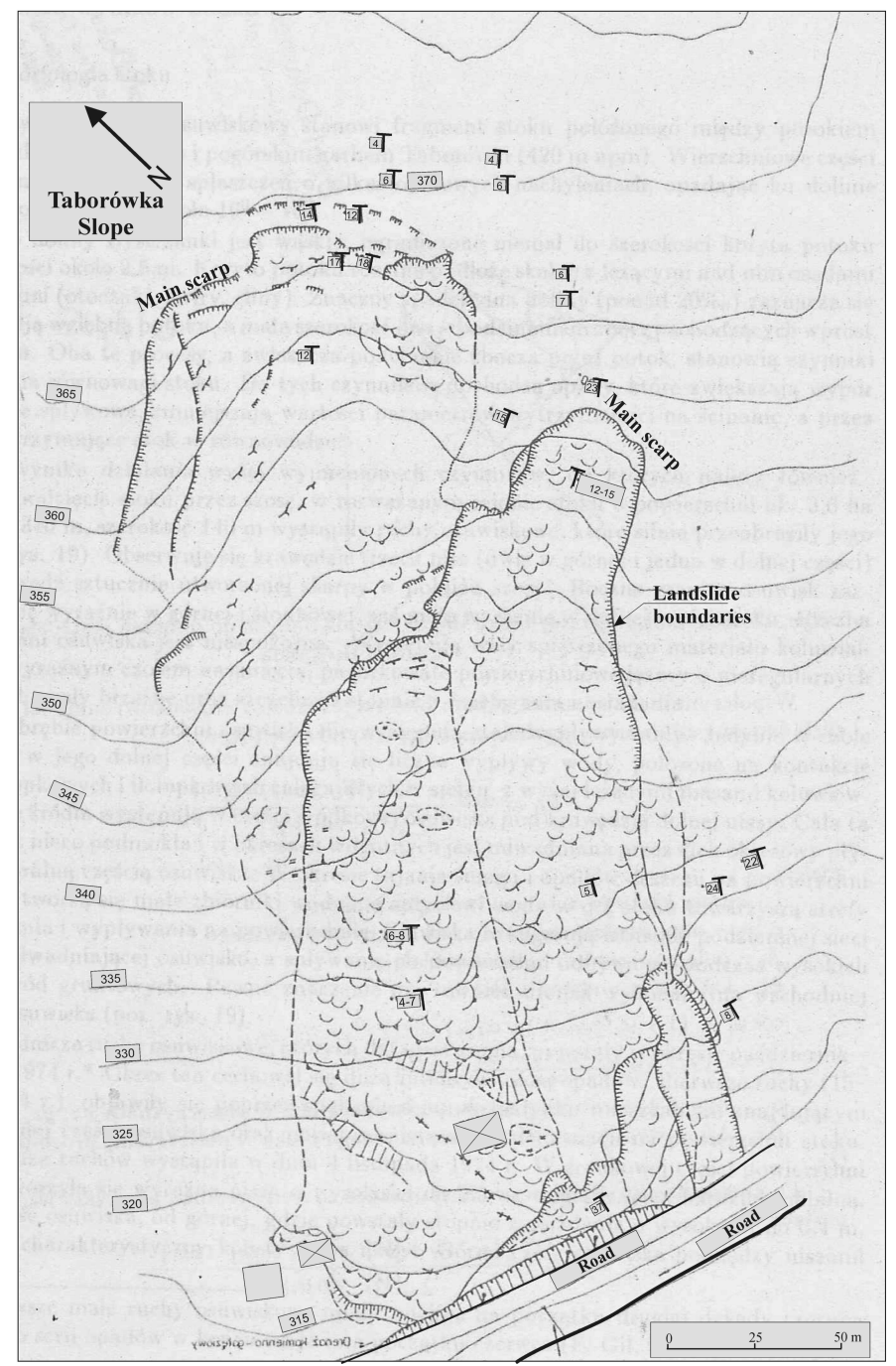

Fig. 3. Geomorphological map of the slope

A road running directly below, at the foot of the landslide slope, causes partially artificial and partially natural slope undercutting (due to draining trenches). Additional important factors activating the landslide movement are precipitation and snow melting.

The ground water level (GWL) is generally high. However, permanent water outflows do not occur within the landslide body, and only some periodic outflows are 
visible in the toe region. The whole slope is watery, and in wet periods a periodic watercourse appears in its central part. In the spring, when the snow is melting and rainfalls are intensive, small reservoirs of water occur on the slope surface, and the ground water level is extremely high. The GWL depth measured in a well located on the slope changes between zero (when the slope is fully saturated with water) and 7 meters. The average depth ranges from 1.4 to $2.0 \mathrm{~m}$.

Despite the presence of mature forms, the landslide is still active, and the movement occasionally accelerates, especially in the lower part of the slope. Since 1974, when a catastrophic slide took place, causing a fall of colluvium material that closed the road, the landslide has been temporarily active, and local movements have been concentrated mainly in the toe zone and below the main scarps. The present condition of the landslide, especially in the S-W frontal part, suggests that there is the danger of the material falling on the road.

Figure 3 presents a cross-section of the landslide along its central axis. Two slip surfaces are seen at depths of $10 \mathrm{~m}(+/-2 \mathrm{~m})$ and 3-4 $\mathrm{m}$. The rock in the zone above the shallow slip surface is decomposed and strongly weathered. The disturbance of the rock-soil mass structure decreases with increasing depth.

\section{Physical and Mechanical Properties of the Rock and Soil}

The granulometric curve, showing the grain distribution of the material, proves that clay, loam, and silt (ca. 80\%), which are products of rock weathering, prevail in the mass. Natural (in situ) moisture is about 20-25\%, and volumetric unit weight is $19.5-20.0 \mathrm{kN} / \mathrm{m}^{3}$. Shear strength parameters are assembled in Table 1.

In preliminary $2 \mathrm{D}$ calculations performed by the limit equilibrium method (Spencer-Davis procedure) for the cross-section shown in Fig. 4, the safety factor $F$ ranged from 0.64 to 1.425 , depending on the depth of the water table. If this depth is smaller, the slope is unstable. It can be said that the slope is in a dynamic equilibrium state,

Table 1. Strength parameters of the soil from the slip zones

\begin{tabular}{|c|c|c|c|c|c|}
\hline \multirow{2}{*}{ Soil } & $\begin{array}{c}\text { Moisture } \\
\text { before } \\
\text { test }\end{array}$ & \multicolumn{2}{|c|}{$\begin{array}{c}\text { Maximum } \\
\text { parameters }\end{array}$} & \multicolumn{2}{c|}{$\begin{array}{c}\text { Residual } \\
\text { parameters }\end{array}$} \\
\cline { 3 - 7 } & $\begin{array}{c}\text { Cohesion } \\
c_{\max } \\
{[\mathrm{kPa}]}\end{array}$ & $\begin{array}{c}\text { Angle of } \\
\text { friction } \phi_{\max } \\
{\left[{ }^{\circ}\right]}\end{array}$ & $\begin{array}{c}\text { Cohesion } \\
c_{\text {res }} \\
{[\mathrm{kPa}]}\end{array}$ & $\begin{array}{c}\text { Angle of } \\
\text { friction } \\
\phi_{\text {res }}\left[{ }^{\circ}\right]\end{array}$ \\
\hline $\begin{array}{c}\text { Silty loam - upper zone } \\
\text { of the landslide }\end{array}$ & 39.50 & 7.1 & 22.75 & $\begin{array}{c}0.0 \\
(12.5)^{*}\end{array}$ & 9.7 \\
\hline $\begin{array}{c}\text { Silty loam - lower zone } \\
\text { of the landslide }\end{array}$ & 37.75 & 7.5 & 18.45 & 8.3 & $(16.0)^{* *}$ \\
\hline Discontinuities & - & 0 & 7.5 & 0 & 7.5 \\
\hline
\end{tabular}

${ }^{*}$ linear approximation; ${ }^{* *}$ unrealistic value (too high) - displacement of the tested specimen is too small 


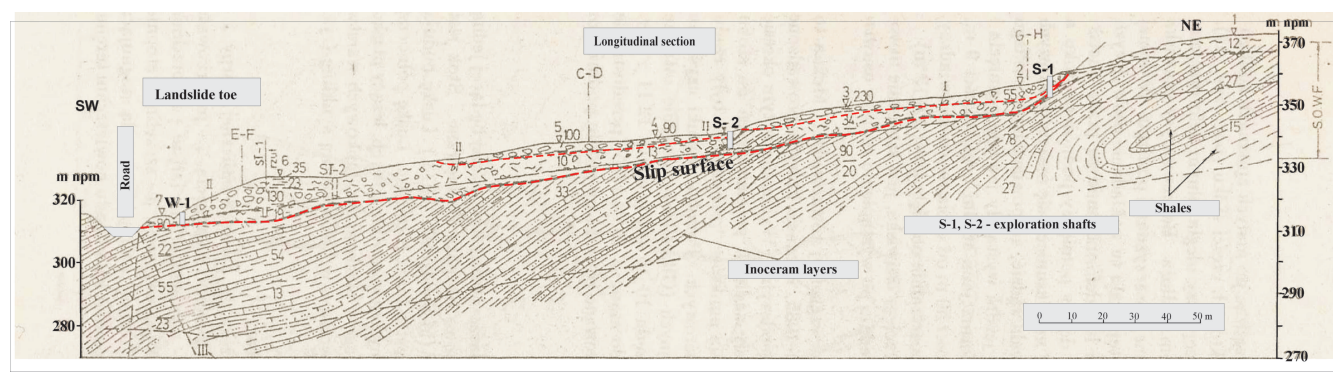

Fig. 4. Cross-section of the central part of the landslide

which means that it is occasionally unstable. The results confirmed that $F$ is 1.0 (or in limit equilibrium) if the water table is about $1.0 \mathrm{~m}$ deep.

\section{Geomechanical Model of the Slope}

The model was developed on the basis of the results of geodetic measurements (Fig. 5). Characteristic features of the surface are bulges in the toe region, a concave shape below the main scarps, and small inclination in the middle part. Due to the lack of displacement measurements, quantitative verification of the landslide simulation re-sults is impossible. However, a qualitative analysis of the characteristic features of the terrain surface makes it possible to check the agreement between the results of the numerical simulation and reality. These features are

- bulges in the toe region the sliding and pouring of the material onto the road prove that the landslide is most dynamic in the lowest part of the slope.);

- movement concentrated in the SW-W part of the toe zone (signs of the slide indi-cate that the movement is directed transversally (in the Y direction) with respect to the central X axis of the landslide. The N-NE part of the lowest landslide zone is more stable than the S-SW part);

- the landslide tongue with a tendency to extend in the S-SW (i.e. Y) direction;

- low activity of the landslide in its middle part and its small inclination;

- two main scarps in the upper part of the slope;

- two slip surfaces at depths of ca. 3-4 m and $10+/-2 \mathrm{~m}$ (see Fig. 4).

The numerical model is relatively simple due to the lack of more accurate data. Figure 6 presents the model divided into two geomechanical zones, namely the bedrock (stable zone) and the landslide (moving colluvium, sliding body). The bedrock is mod-eled as elastic, and the colluvium zone as elasto-ideally plastic (obeying the Coulomb-Mohr failure criterion), isotropic, homogeneous and continuous. The elasticity param-eters are modulus $E=100 \mathrm{MPa}$ and Poisson's coefficient $v=0.35$. Due to an earlier large displacement of the slope, residual shear strength parameters were assumed (Table 2).

Despite small differences between the strength parameters of rocks and discontinuities (see Table 2), the orientation of the discontinuities has significant influence on 


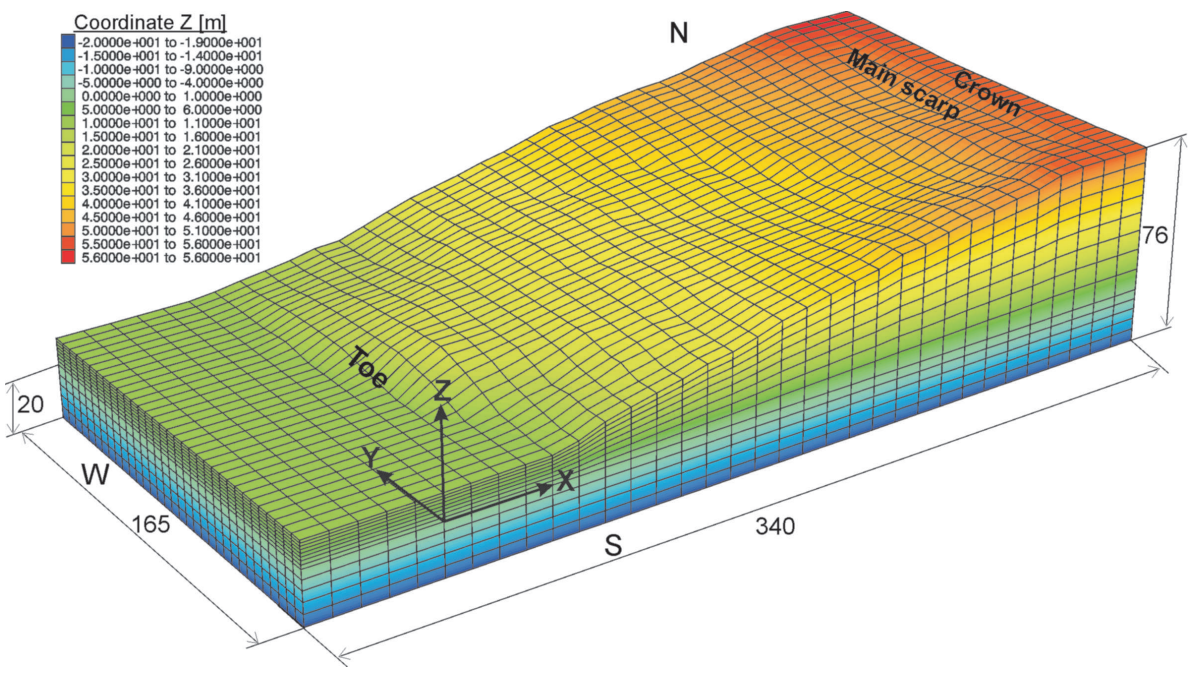

Fig. 5. Geometry of the 3D numerical model

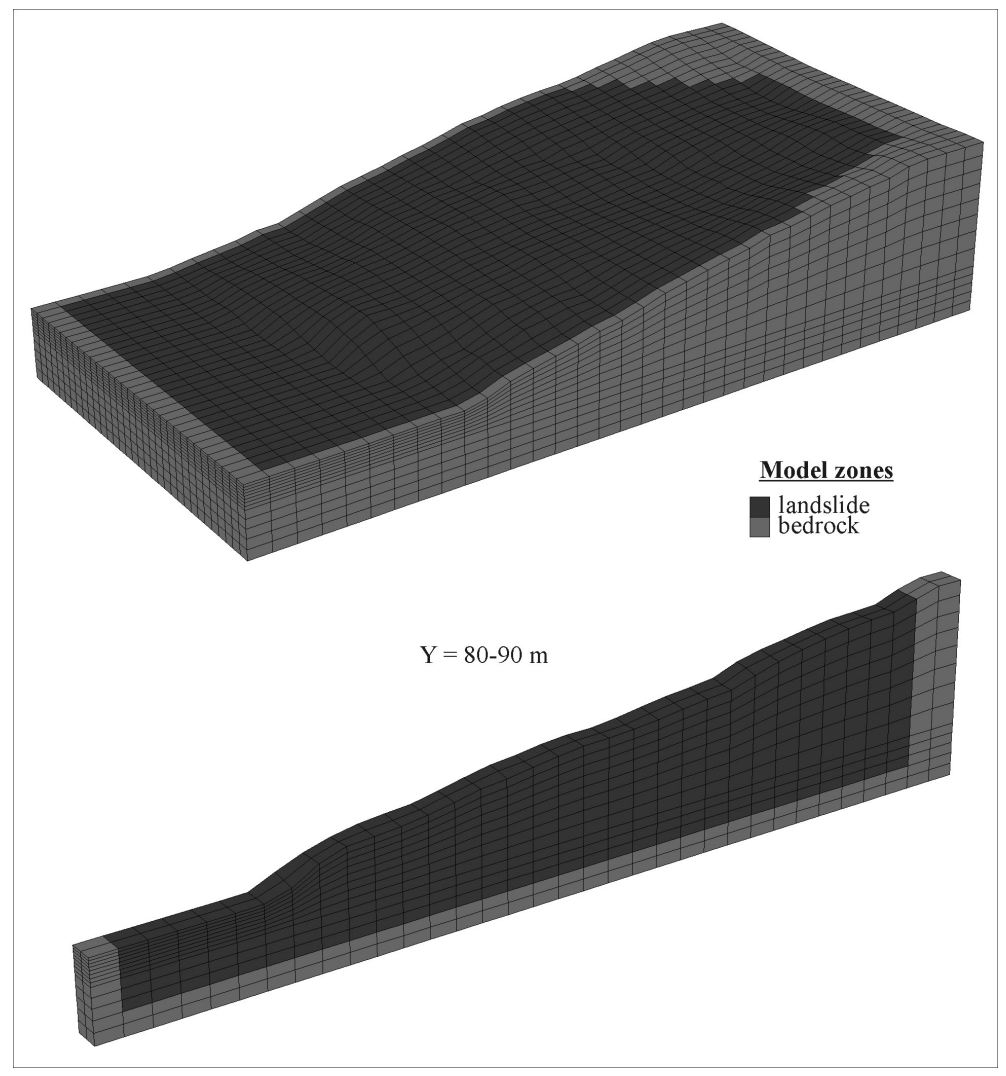

Fig. 6. Model of the slope with landslide boundaries 
Table 2. Strength parameters in the numerical model

\begin{tabular}{|c|c|c|c|c|}
\hline Zone & $\begin{array}{c}\text { Cohesion } \\
\qquad \begin{array}{c}c \\
{[\mathrm{kPa}]}\end{array}\end{array}$ & $\begin{array}{c}\text { Friction } \\
\text { angle } \\
\phi \\
{\left[{ }^{\circ}\right]}\end{array}$ & $\begin{array}{c}\text { Dilatation } \\
\text { angle } \\
\xi^{*} \\
\left.{ }^{\circ}\right]\end{array}$ & $\begin{array}{c}\text { Uniaxial tension } \\
\text { strength } \\
R_{r} \\
{[\mathrm{kPa}]}\end{array}$ \\
\hline External zone (bedrock) & $2 \mathrm{E}+6$ & 50 & 15 & $2 \mathrm{E}+6$ \\
\hline Internal zone (landslide) & 0 & 9.7 & 2 & 0 \\
\hline Discontinuities & 0 & 7 & 3.5 & 0 \\
\hline
\end{tabular}

landslide deformation processes. This problem was tested by a numerical simulation of the landslide for six models of the rock mass with ubiquitous discontinuities (Itasca 1997). The six models are shown in Fig. 7. The discontinuity orientation in Fig. 7a is "consequent" both with the dip direction of the slope $\left(270^{\circ}\right)$ and with slope inclination $\left(7.5^{\circ}\right)$. The models in Figs. $7 \mathrm{~b}$ and $7 \mathrm{c}$ represent the "insequent" orientation, in which the dip directions of the discontinuities are the same as the dip direction of the slope, but their dip angles are different. The models in Figs. 7d and 7e show the "subsequent" configuration, in which both the dip directions and dip angles of the discontinuities and of the slope are different. In all ubiquitous models, full saturation of the slope is assumed. In the case of isotropic models, two variants were analyzed, namely the dry slope and the wet (fully saturated) slope.

\section{Description and Discussion of the Results of Landslide Simulation}

The initial geometry of the slope models agrees with the present state of the slope. This means that the results of the simulation predict future deformations of the slope. It should be pointed out that equilibrium was reached in the simulation only in the case of the dry slope. All other simulations were stopped arbitrarily, and the continuation of calculations would have generated further displacements. The moment of discontinuing the simulation which was partly arbitrary was connected with the impossibility of reaching the equilibrium state independently of very large displacements as well as extensive and curious deformations of the finite difference zones.

The main features of the deformation processes for the dry and wet slopes are tabulated in Table 3.

Displacement diagrams in the $\mathrm{X}, \mathrm{Y}$, and $\mathrm{Z}$ directions for the "dry" and "wet" isotropic models are presented in Fig. 8. Similar diagrams for consequent, insequent and subsequent models are shown in Figs. 9, 11, and 13, respectively. Displacement ratios $U_{x}$ calculated in the lowest, middle and upper parts of the landslide are assembled in Table 4 to facilitate the comparison of deformation dynamics.

The results prove that the largest displacement in the $\mathrm{X}$ direction in all models is generated in the toe of the landslide, and the smallest in its middle part. The most active dynamics of the displacement in the toe region is observed in the case of the 

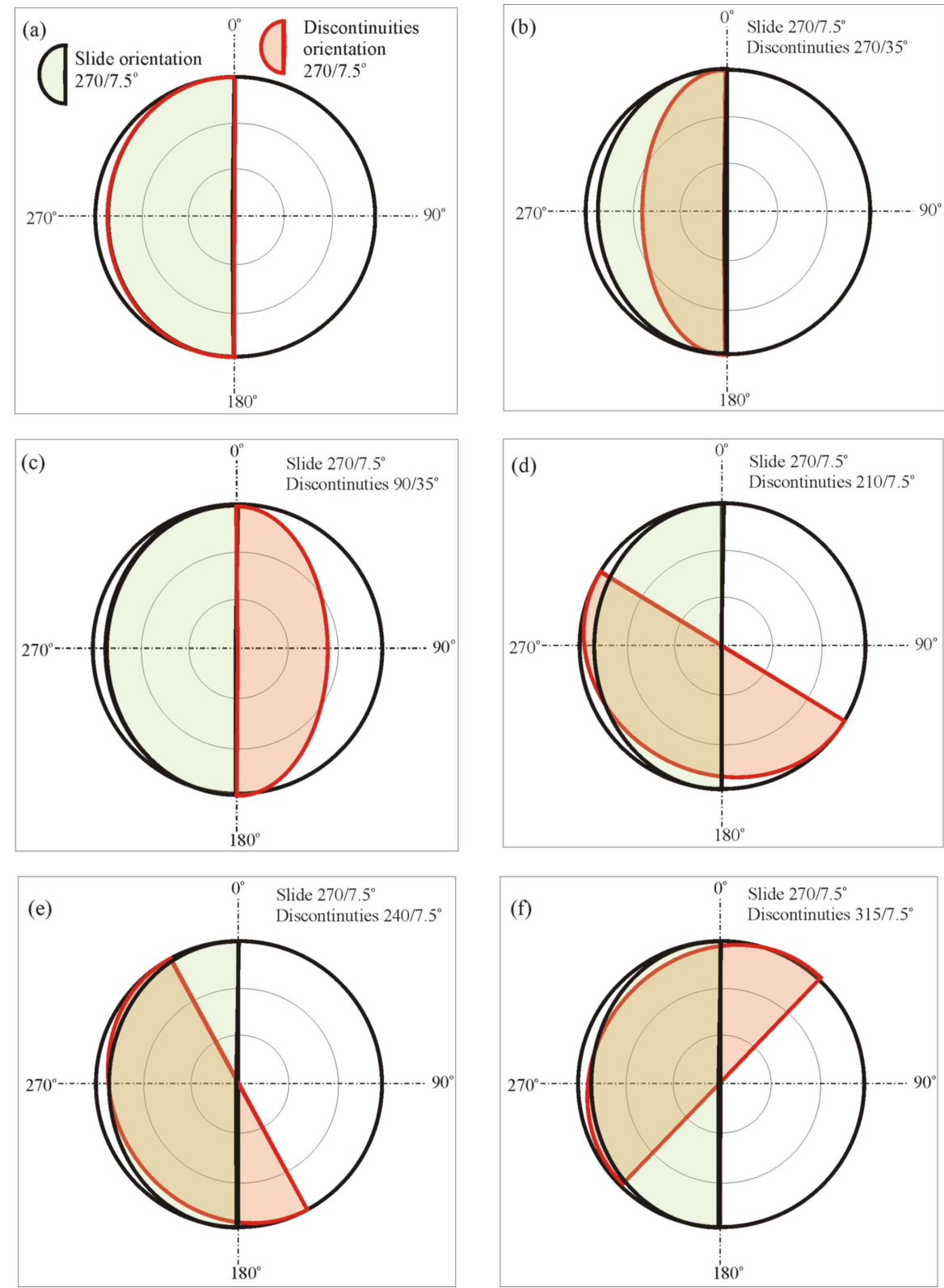

Fig. 7. Orientation of discontinuities in the models analyzed: (a) consequent 270/7.5

(b) insequent $270 / 35^{\circ}$, (c) insequent $90 / 35^{\circ}$, (d) subsequent $210 / 7.5^{\circ}$, (e) subsequent $240 / 7.5^{\circ}$, (f) subsequent $315 / 7.5^{\circ}$

insequent orientation of discontinuities and in the isotropic model of the dry toe region. Displacements in the main scarp (niche) are considerably smaller than those in the toe. Only in the subsequent models these differences are small. The landslide 
Table 3. Features of deformation modes for the dry and wet slopes

\begin{tabular}{|l|l|}
\hline \multicolumn{1}{|c|}{ Dry slope } & \multicolumn{1}{c|}{ Wet slope } \\
\hline $\begin{array}{l}\text { big } U_{y}, \text { expansion of the landslide tongue in } \\
\text { both directions }+/-Y\end{array}$ & $\begin{array}{l}U_{y} \text { in the tongue region is smaller than in } \\
\text { the case of the dry slope }\end{array}$ \\
\hline small elevation of the road pavement & big elevation of the road \\
\hline $\begin{array}{l}\text { low deformation intensity in the upper part } \\
\text { of the slope (main scarp region) }\end{array}$ & $\begin{array}{l}\text { large deformations in the region of the } \\
\text { main scarp }\end{array}$ \\
\hline $\begin{array}{l}\text { poorly developed edge of the main scarp on the } \\
\text { north side in the northern part of the landslide }\end{array}$ & $\begin{array}{l}\text { clearly structured edge of the main scarp on } \\
\text { the north side }\end{array}$ \\
\hline
\end{tabular}

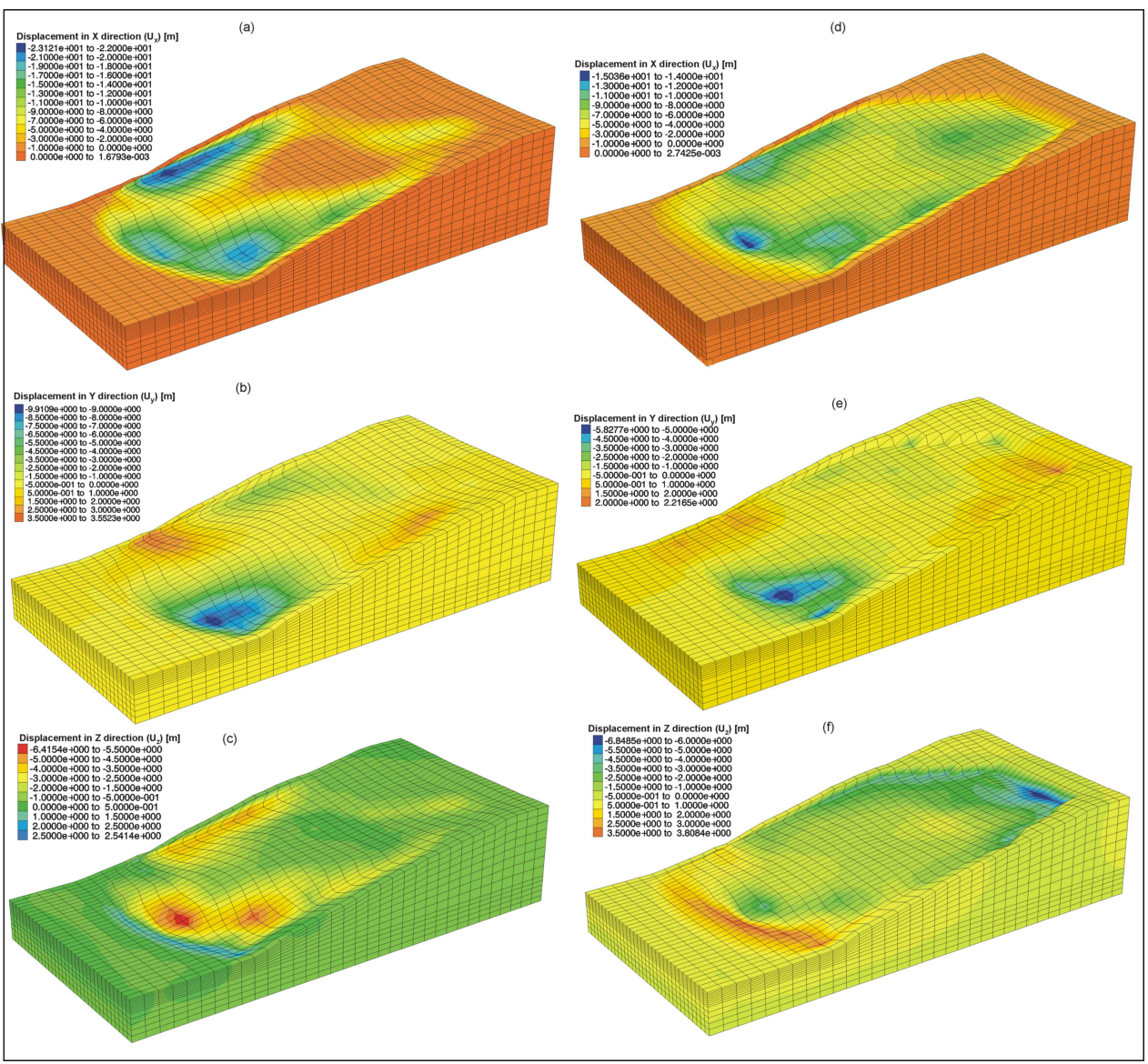

Fig. 8. Displacements of the slope. Isotropic model. Dry slope: (a) $U_{x}$, (b) $U_{y}$, (c) $U_{z}$. Wet (fully saturated) slope: (d) $U_{x}$, (e) $U_{y}$, (f) $U_{z}$ the basis of changes of the terrain morphology. 
Table 4. Relations of displacements in different parts of the landslide

\begin{tabular}{|l|c|c|c|}
\hline \multicolumn{1}{|c|}{ Model } & $U_{\text {xmiddle }} / U_{\text {xtoe }}$ & $U_{\text {xniche }} / U_{\text {xtoe }}$ & $U_{\text {xmiddle }} / U_{\text {xniche }}$ \\
\hline Isotropic, dry slope & 0.148 & 0.143 & 1.0347 \\
\hline Isotropic, wet slope & 0.486 & 0.648 & 0.750 \\
\hline Consequent, 270/7.5 & 0.535 & 0.910 & 0.587 \\
\hline Insequent, 270/35 & 0.184 & 0.270 & 0.680 \\
\hline Insequent, 90/35 & 0.149 & 0.400 & 0.370 \\
\hline Subsequent, 210/7.5 & 0.545 & 0.935 & 0.583 \\
\hline Subsequent, 240/7.5 & 0.502 & 0.930 & 0.540 \\
\hline Subsequent, 315/7.5 & 0.472 & 0.859 & 0.550 \\
\hline
\end{tabular}

In the isotropic homogeneous model, when the slope is dry, the main scarp is poorly developed (see Fig. 8a-c). The relatively big displacement Uy, perpendicular to the dip direction of the slope, is characteristic of debris flows. Such a mechanism is observed in the slope analyzed here. In the case of a wet slope (Fig. 8d-f), the main scarp de-velops dynamically, mainly by subsidence and with a relatively small displacement in the $\mathrm{X}$ direction i.e. $U_{x}$. The landslide tongue above the road declines, whereas the road pavement rises. Such elevation is seen in reality; it amounts to several dozen centimeters and continues to increase.

Deformation processes in the subsequent models do not depend on the specific orientation of the discontinuities. In all cases, a large subsidence of the main scarp is seen, as well as a relatively small $U_{y}$ displacement in the S-W region and a distinct $U_{y}$ displacement in the $\mathrm{N}$ region.

The depth of the slide, the number of slip surfaces, and deformation dynamics in dif-ferent parts of the slope can be estimated on the basis of the distribution of maximum shear strain increments (SSI), which can be considered as an attribute of the slide zone. To determine the fields of these increments, three sections were chosen parallel to the $X$ axis (see Fig. 4), namely $Y=30-40 \mathrm{~m}$ (southern side of the landslide), $\mathrm{Y}=80-90 \mathrm{~m}$ (central section) and $\mathrm{Y}=130-140 \mathrm{~m}$ (northern side).

Fig. 9 presents SSI in the isotropic and homogeneous models. As seen in Fig. 9a, a shallow slide is created in the dry slope, with activity concentrated in the toe zone. The maximum depth of the slide zone is about $5 \mathrm{~m}$. In the region of the main scarp, some signs of SSI concentration and two shallow slides are seen only in the central section ( $\mathrm{Y}=80-90 \mathrm{~m}$ ). If the slope is fully saturated (Fig. 9b), an extensive slide (i.e. a SSI concentration) with an approximately circular shape appears at a maximum depth of about 20-23 m. A concentration of SSI is also seen at a depth of 3-4 m in the toe region and, less intensive, near the main scarp. The magnitude of SSI is approximately equal in all three cross-sections.

Effects similar to those described above occur also in the model of the slope with the consequent orientation of discontinuities (Fig. 10), but the elevation of the road is smaller than in the isotropic, homogeneous model. The landslide movement in differ- 


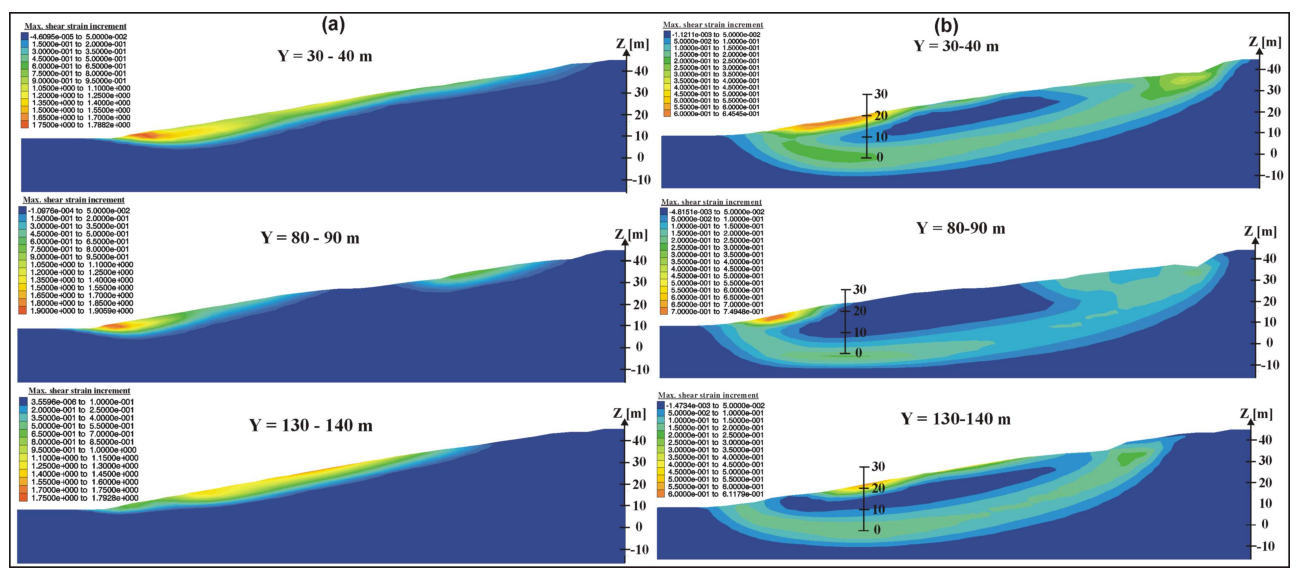

Fig. 9. Maximum shear strain increments in selected cross-sections. Isotropic homogeneous model: (a) dry slope, (b) wet slope

ent cross-sections in this model is differentiated (Fig. 11). In the section $\mathrm{Y}=30-40$ $\mathrm{m}$, a translational landslide is created with a depth of about 9-10 m. In the middle section, two shallow slides are visible with circular shapes of the slip surface, and in the N-E side shallow slides are created in the lower and middle regions. The intensity of the slide is greatest in the toe zone.

In the model with insequent orientation of discontinuities equal to $270 / 35^{\circ}$ (Fig. $12 \mathrm{a}-\mathrm{c})$, the deformation dynamics of the main scarp is low, and its shape is smooth and rounded. If the orientation is $90 / 35^{\circ}$ (Fig. 12d-f), the shape is more angular although vertical displacement is approximately equal to the one described above. In this model - in which the dip direction of discontinuities agrees with the slope dip direction, i.e. $270 / 35^{\circ}$ (see Fig. $7 b$ ) - displacements in the $X$ direction are approximately twice as large as in the case of the $90 / 35^{\circ}$ orientation. Moreover, a significant slide is present in all cross-sections at a depth of about $10 \mathrm{~m}$, with SSI concentration mainly in the lower part of the slope (Fig. 13). Deformation intensity decreases from S-W to N-E. The intensity of SSI in the region of the main scarp is low. It is worth mentioning that if the dip direction of discontinuities $\left(90^{\circ}\right)$ is opposite to the dip direction of the slope $\left(270^{\circ}\right)$, the shape of the slide is similar to that in the consequent model. The depth of the slide surface in the lower part of the slope on the $\mathrm{S}-\mathrm{W}$ side $(\mathrm{Y}=30-40 \mathrm{~m})$ is about $10 \mathrm{~m}$ and decreases towards the north $(\mathrm{Y}=130-140 \mathrm{~m})$. There is a noticeable tendency for the creation of small secondary shallow slides.

The deformation mechanism in the case of the subsequent orientation of discontinuities is similar, and a large subsidence of the main scarp is seen in all three cases of discontinuity orientation with different dip directions, i.e. $210^{\circ}, 240^{\circ}$, and $315^{\circ}$ (Fig. 14) $)^{*}$. A translational landslide develops at a depth of approximately $10 \mathrm{~m}$, extending

The case of orientation $240 / 7.5^{\circ}$ is not shown here, as it is very similar to those presented in the figures. 


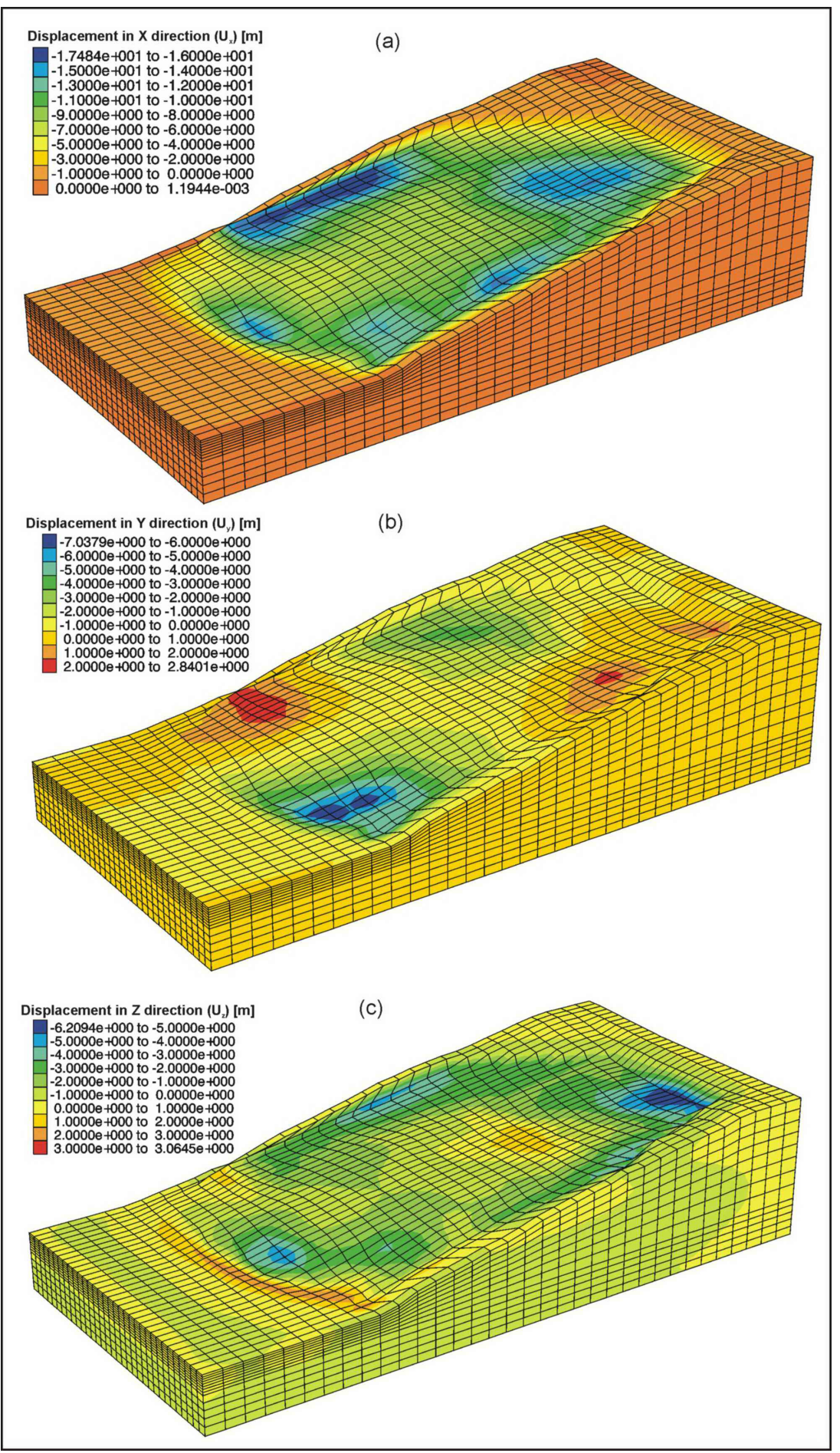

Fig. 10. Displacements of the slope. Consequent model: (a) $U_{x}$, (b) $U_{y}$, (c) $U_{z}$ 


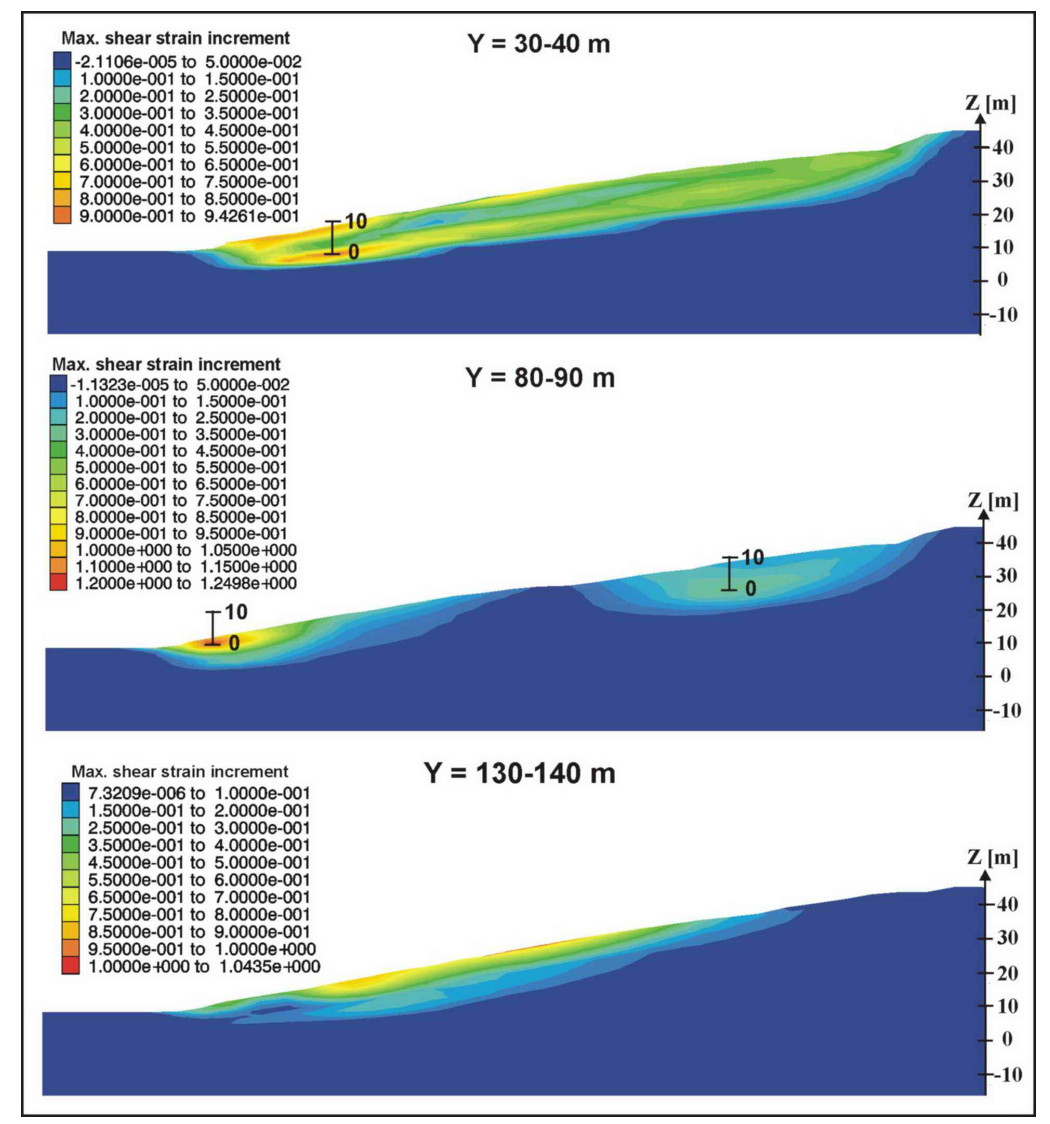

Fig. 11. Maximum shear strain increments in selected cross-sections. Consequent model of the orientation of discontinuities

along the whole slope. The intensity of SSI decreases from S-W to N-E and from the toe to the main scarp (Fig. 15). In the toe region, secondary slides develop in the cross-sections $\mathrm{Y}=30-40 \mathrm{~m}$ and $\mathrm{Y}=80-90 \mathrm{~m}$.

The comparison of the landslide shape determined by geological investigations with the tendencies suggested by calculations proves that the layered structure of the landslide plays an important role in deformation processes. In fact, the shape of the slip surface is significantly different from circular, generated in the case of a homogeneous massif.

Due to tectonic disturbances, the orientation of geological structures (layers and discontinuities) under natural conditions is variable, and thus it is impossible to determine unambiguously which structural model is the best. It seems, however, that the deformation mechanism with deeper slip surfaces in the case of insequent and subsequent orientations is closer to reality. Shallow slides are generated only in the shallow zone, where the rock mass structure is strongly disintegrated (due to weathering and erosion) and the mass can be considered as isotropic. 


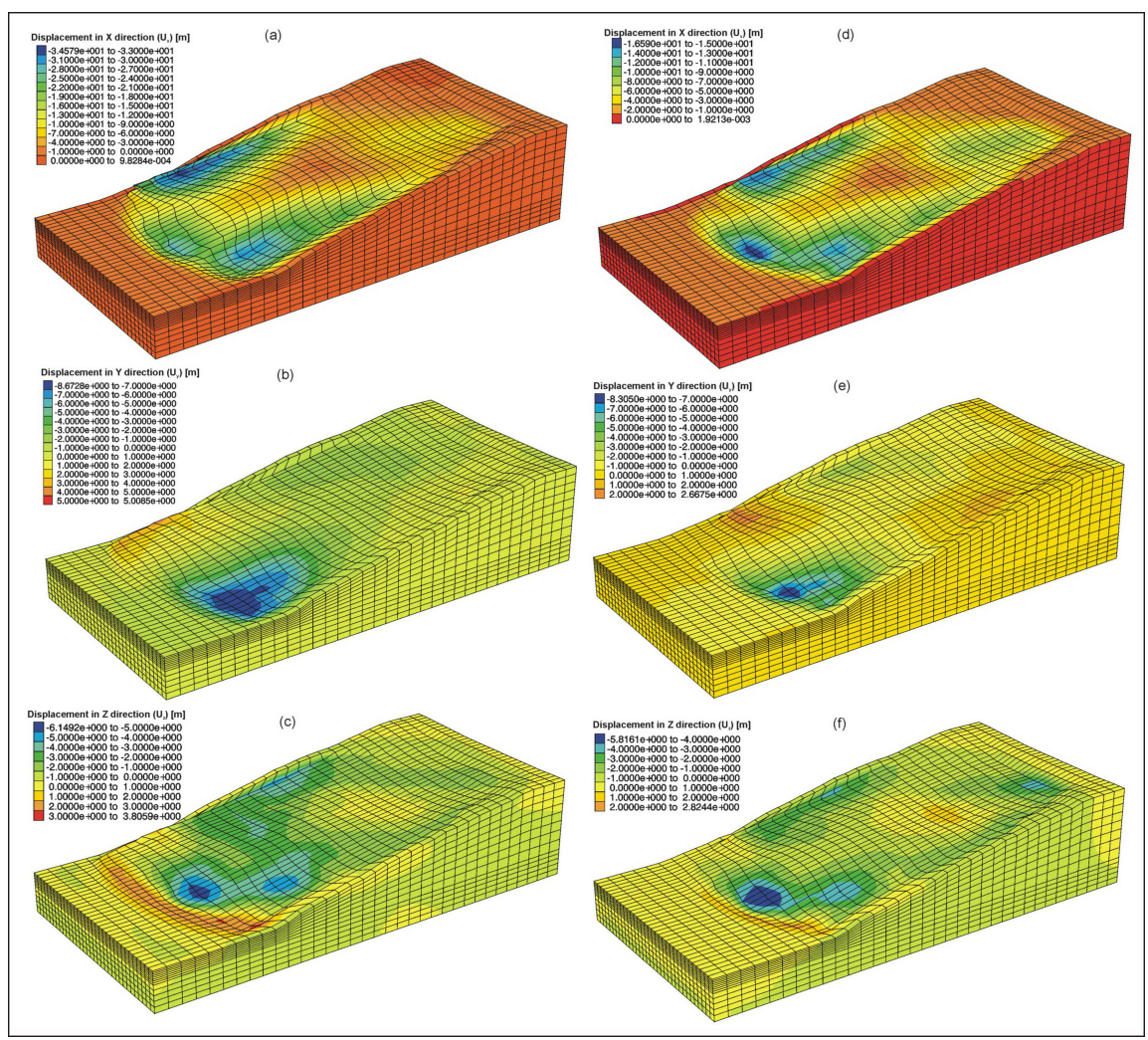

Fig. 12. Displacements of the slope. Insequent model: orientation of discontinuities $270 / 35^{\circ}$ (a) $U_{x}$, (b) $U_{y}$, (c) $U_{z}$; orientation of discontinuities $90 / 35^{\circ}$ (d) $U_{x}$, (e) $U_{y}$, (f) $U_{z}$

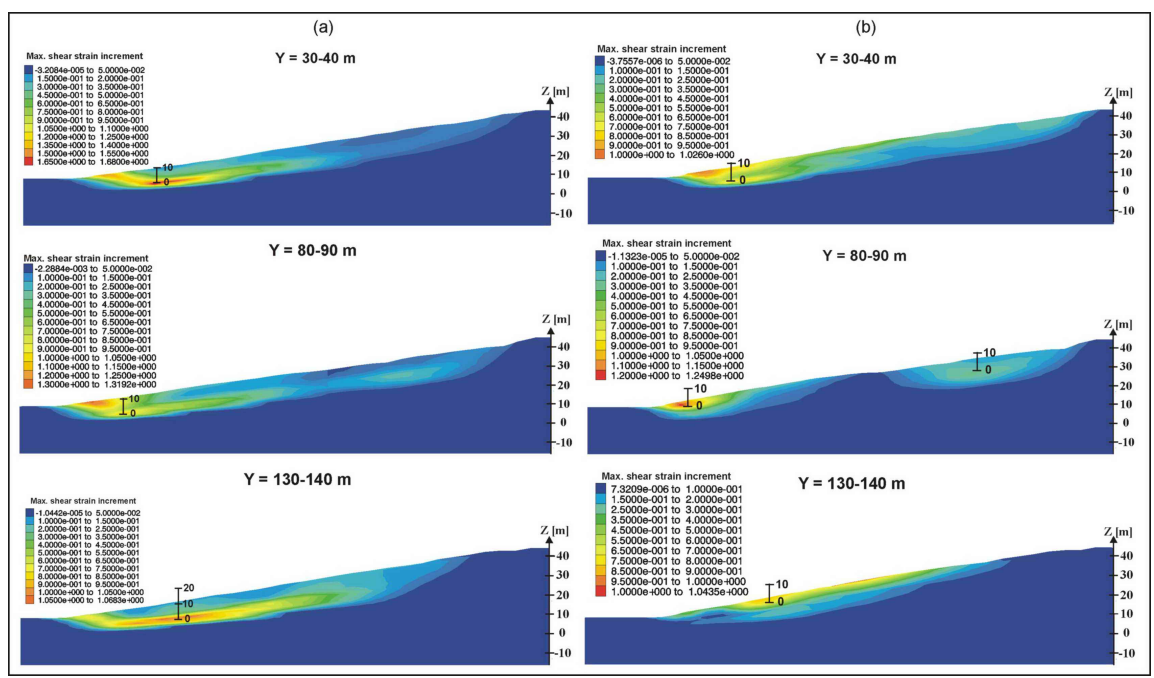

Fig. 13. Maximum shear strain increments in selected cross-sections. Insequent model: (a) orientation of discontinuities $270 / 35^{\circ}$; (b) orientation of discontinuities $90 / 35^{\circ}$ 


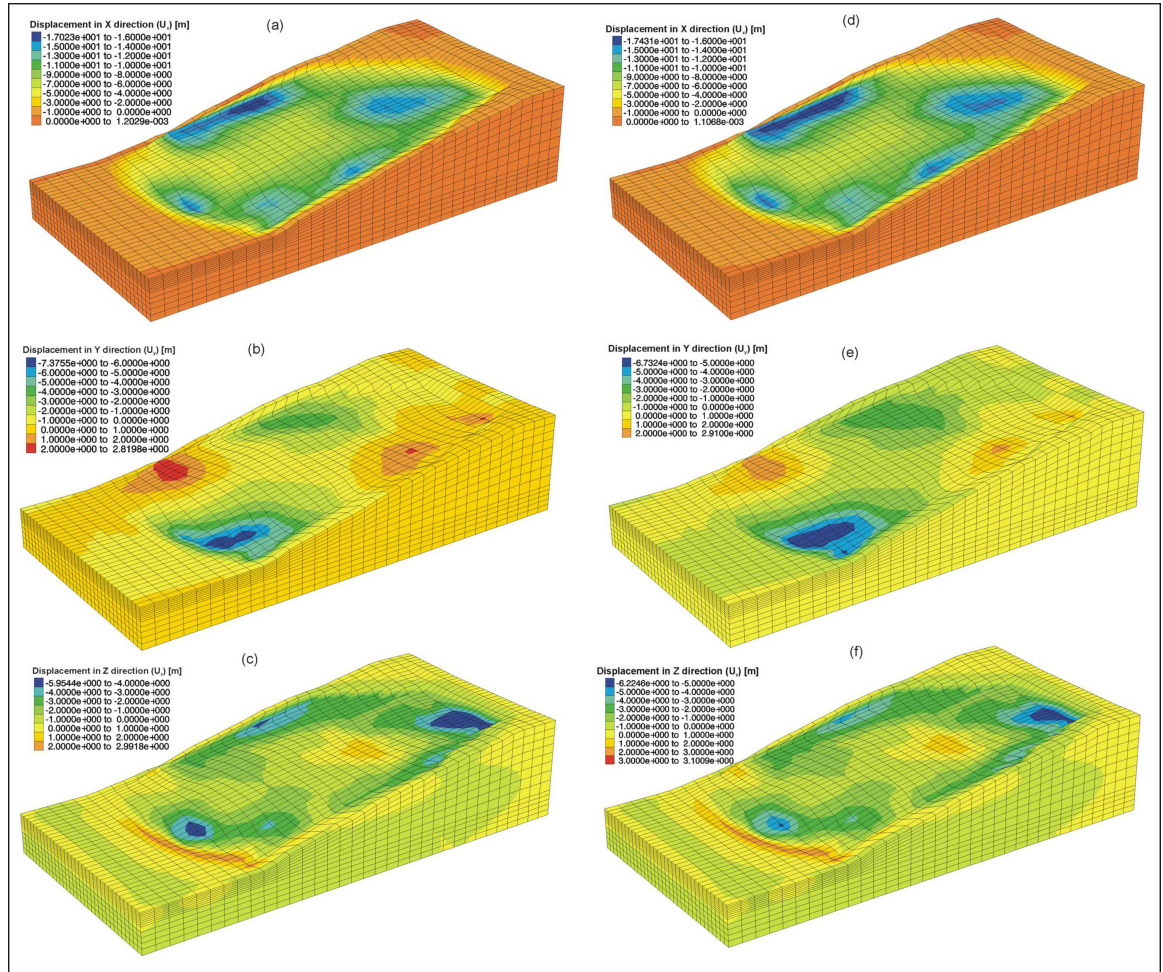

Fig. 14. Displacements of the slope. Subsequent model: orientation of discontinuities $210 / 7.5^{\circ}$ (a) $U_{x}$, (b) $U_{y}$, (c) $U_{z}$; orientation of discontinuities $315 / 7.5^{\circ}$ (d) $U_{x}$, (e) $U_{y}$, (f) $U_{z}$

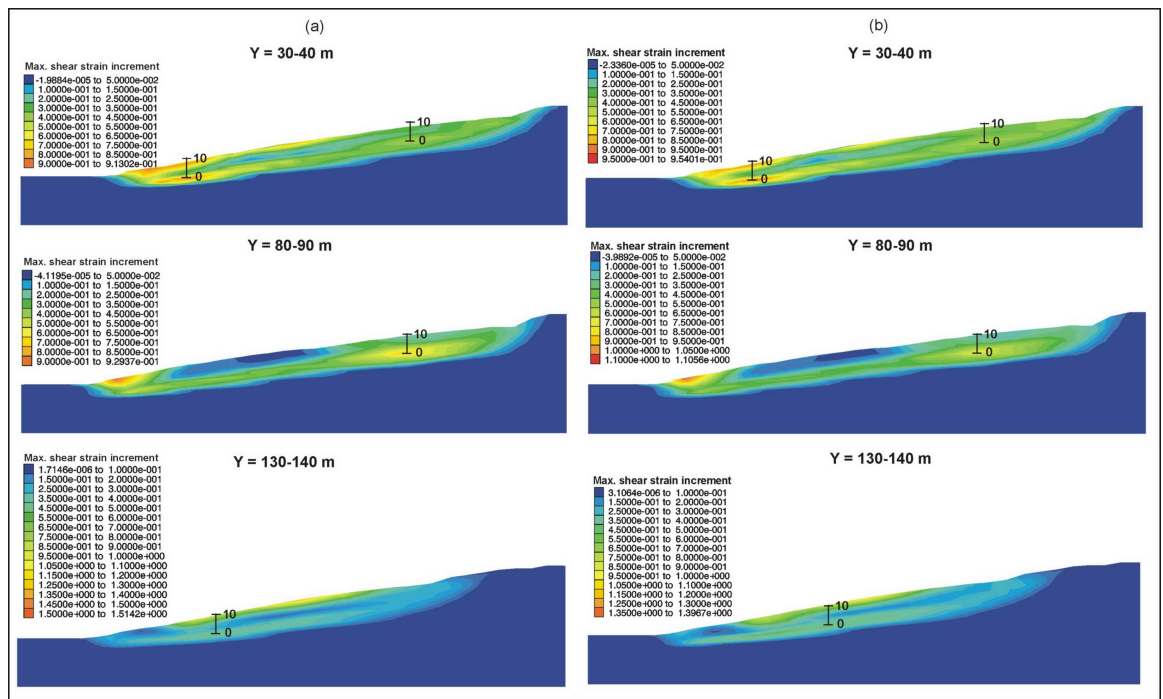

Fig. 15. Maximum shear strain increments in selected cross-sections. Subsequent model: (a) orientation of discontinuities $210 / 7.5^{\circ}$; (b) orientation of discontinuities $315 / 7.5^{\circ}$ 


\section{Summary and Conclusions}

Some detailed conclusions are presented in the previous sections, and what follows are more general conclusions and remarks:

1) The depth of the rock mass involved in the movement increases with the decreasing depth of the water table; the dry slope in the present simulation reached an equilibrium state, whereas the wet slope moved continuously until the simulation was stopped arbitrary.

2) The variability of the slope inclination in different zones has a decisive influence on the magnitude and rate of displacement, although this variability does not wholly explain the variability of deformation processes.

3) The landslide deformation process depends on the presence and orientation of tec-tonic structures in the slope. The structural character of the rock mass causing dependence of the landslide forms from the structure explains the plane or almost plane slip surface (translational landslide). A circular slip surface is created when the rock mass is homogeneous.

4) The results show that the "absolutisation" of the position and course of the slip surface is the wrong approach. They can change depending on hydrogeological conditions and the cross-section selected. Also the results of inclinometric measurements show that the location of the slip surface can change with time, and new slip surfaces emerge during the measurement period (Zabuski 2013).

An important and difficult problem in the 3D modeling and simulation of a landslide process is usually the lack of data from terrain investigations (Arellano and Stark 2000). It is almost a rule that even the construction of a $2 \mathrm{D}$ model (i.e. a cross-section) entails difficulties, whereas to create a 3D model is a much more complicated task. There are some cases, however, in which the 3D approach is necessary, although difficult to implement. The present simulation is an example of such a case.

\section{References}

Arellano D., Stark T. D. (2000) Importance of three-dimensional slope stability analysis in practice, [In:] Griffiths et al (Eds.), Slope Stability 2000, GSP 101, Reston, ASCE, 18-32.

Bober L., Thiel K., Zabuski L. (1997) Landslide phenomena in the Polish Carpathian Flysch: Geological and engineering properties of selected landslides, Wydawnictwo IBW PAN, Gdańsk, 1997 (in Polish).

Bober L., Zabuski L. (1993) Flysch Slope Classification from Viewpoint of the Landslide Prediction, Proc. Int. Symp. "Geotechnical Engineering of Hard Soils-Soft Rocks", Athens 1993, A.A. Balkema, Rotterdam - Brookfield, Vol. 2, 1065-1072.

Chen R. H., Chameau J. L. (1982) Three-dimensional limit equilibrium analysis of slopes, Geotechnique, 32 (1), 31-40.

Dauksza L., Kotarba A. (1973) An analysis of the influence of fluvial erosion in the development of landslide slope, Studia Geomorph. Carpatho-Balcanica, No.7, 91-104.

Detournay Ch., Hart R. (eds.) (1999) FLAC and Numerical Modeling in Geomechanics, Proc. Int. FLAC Symp. on Numerical Modeling in Geomechanics, Minneapolis, Sept. 1999, Balkema/Rotterdam/Brookfield. 
Griffiths D. V., Marquez R. M. (2007) Three-dimensional slope stability analysis by elasto-plastic finite elements, Geotechnique, 57 (6), 537-546.

Hungr O., Salgado F. M., Byrne P. M. (1989) Evaluation of three-dimensional method of slope stability analysis, Can. Geotech. J.. 26 (4), 679-686.

Itasca (1997) FLAC3D User's Manual, Version 2, Minneapolis, USA.

Lam L., Fredlund D. G. (1993) A general limit equilibrium model for three-dimensional slope stability analysis, Can. Geotech. J., 30 (6), 905-919.

Silvestri V. (2006) A three-dimensional slope stability problem in clay, Can. Geotech. J., 43 (2), 224-228.

Stark T. D., Eid H. T. (1998) Performance of three-dimensional slope stability methods, J. Geotech. Geoenviron. Engng, 124 (11), 1049-1060.

Thiel K. ed. (1989) Formation of flysch Carpathian slopes by mass movements: The case of the Bystrzyca slope in Szymbark, Prace IBW PAN No. 17, Gdańsk (in Polish).

Zabuski L. (2008) Investigation of the mechanism of landslide movement on the test slope including the influence of external factors and internal properties of the rock mass, IBW PAN, Gdańsk (internal report), (in Polish).

Zabuski L. (2013) Assessment of landslide processes based on the results of inclinometric measurements, Przeglad Geologiczny, 61 (4), 248-256 (in Polish).

Zabuski L., Thiel K., Bober L. (1999) Landslides in the flysch of the Polish Carpathians: Geology, Modelling, Stability Calculations, Wydawnictwo IBW PAN, Gdańsk, 171 p. (in Polish).

Zabuski L. (2006) Numerical three-dimensional modelling of the landslide process in the Carpathian Flysch, Proc. Int. Conf. "Mass Movement Hazard in Various Environments", Polish Geological Institute Special Papers 20, 20-21.10.2005, Kraków, 114-118.

Zabuski L., Wójcik A., Gil E., Mrozek T., Rączkowski W. (2009) Landslide process in a flysch massif - case study of the Kawiory landslide, Beskid Niski Mts. (Carpathians, Poland), Geological Quarterly, 53 (3), PGI, Warsaw, 317-332.

Zabuski L. (2018) The influence of slope geometry on its stability: Spatial and plane analysis, Archives of Hydro-Engineering and Environmental Mechanics (AHEM), 65 (4), 243-254. 